\title{
KHALAYAK TWITTER AKSI "REUNI 212" 2018: JARINGAN VIRTUAL COMMUNITY DAN DIGITAL MASQUERADING
}

\author{
Ali Al Harkan', Irwansyah² \\ 'Mahasiswa Pascasarjana Departemen Ilmu Komunikasi, Fakultas IImu Sosial dan IImu Politik \\ ${ }^{2}$ Dosen Departemen IImu Komunikasi, Fakultas IImu Sosial dan IImu Politik \\ Universitas Indonesia, Kampus Salemba 16424 \\ Email: ${ }^{1} a l i . a l 81 @ u i . a c . i d,{ }^{2}$ dr.irwansyah.ma@gmail.com
}

\begin{abstract}
ABSTRAK
Fenomena Reuni Akbar 212 yang dilaksanakan pada 2 Desember 2018 adalah fenomena yang menarik, sebab tingginya partisipasi kelompok Islam yang berjumlah puluhan hingga ratusan ribu tersebut bermula dari aksi 212 yang semula hanya diikuti oleh ribuan anggota FPI. Salah satu faktor yang mempengaruhi signifikannya peningkatan jumlah peserta aksi dari Aksi Bela Islam I hingga kemarin melakukan reuni yang kedua, adalah adanya aktivitas komunikasi Aksi 212 melalui media sosial. Penelitian ini memiliki rumusan masalah untuk mendalami bagaimana fenomena khalayak aksi Reuni 212 di media sosial Twitter sebagai sebuah komunitas virtual (virtual community) yang membangun jaringan komunikasi. Dengan menggunnakan konsep virtual community Howard Rheingold sebagai pendekatan analisis, serta metode analisis jaringan komunikasi untuk mengetahui pola struktur jaringan komunikasi komunitas yang terjadi, penulis menemukan bahwa 1000 pengguna Twitter yang termasuk dalam jaringan tagar \#ReuniAkbar212 pada 2 Desember 2018 merupakan sebuah fenomena komunitas virtual sebagaimana konsepsi Rheingold. Analisis dengan pendekatan teori virtual community menemukan bahwa komunitas virtual pengguna Twitter dalam jaringan tagar \#ReuniAkbar212 mencerminkan adanya aktivitas komunikasi yang dimediasi komputer dan jaringan internet di antara para pengguna yang direpresentasikan oleh akun Twitter; aktivitas komunikasi yang terjadi tersebut dalam terminologi Twitter antara lain berupa tweeting, mentioning, replying, dan retweeting; adanya etos berbagi informasi dalam komunitas yang ditunjukkan dengan tingginya jumlah tweet; dan juga terdapat fenomena kepatuhan netiquette komunitas virtual berupa menghindari penggunaan hurufhuruf kapital agar tidak mengesankan kalimat teriakan. Analisis jaringan komunikasi juga menemukan bahwa akun Twitter @prabowo adalah pusat konsentrasi jaringan komunikasi tagar \#ReuniAkbar212. Di sisi lain, analisis digital masquerading menemukan bahwa 71,2\% pesan-pesan di dalam komunitas bukanlah bernada politik, sementara $28,8 \%$ yang lain adalah komunikasi politik namun tidak adanya indikasi pelaksanaan taktik digital masquerading.
\end{abstract}

Kata kunci: Reuni Akbar 212, Twitter, virtual community, jaringan komunikasi, digital masquerading.

\section{A. PENDAHULUAN}

\section{Aksi Reuni 212 dan Konteksnya}

Pada Minggu, 2 Desember 2018, area Tugu Monumen Nasional Jakarta dan sekitarnya 'memutih' karena berkumpulnya peserta kegiatan Reuni 212, mengenakan baju serba putih. Kegiatan ini merupakan kegiatan kedua setelah pada tahun sebelumnya juga telah dilakukan aksi serupa, Reuni 212 pada 2 Desember
2017. Kegiatan 212, atau kerap disebut sebagai Aksi 212, merujuk pada pada aksi berkumpulnya ribuan massa pada 2 Desember 2016 di Jakarta untuk kembali menunut Gubernur DKI Jakarta nonaktif kala itu, Basuki Tjahaja Purnama (Ahok), yang telah ditetapkan sebagai tersangka kasus dugaan penistaan agama. Aksi pada 2 Desember 2016 ini juga disebut sebagai Aksi Damai 2 Desember. 
Secara latar belakang, aksi pertama dipicu oleh dugaan penistaan agama yang dilakukan oleh Ahok yang kala itu menjabat sebagai Gubernur DKI Jakarta petahana dan dalam konteks kampanye Pemilihan Gubernur. Pada 27 September 2016, Ahok melakukan kunjungan kerja ke Pulau Pramuka di Kepulauan Seribu untuk meninjau program budidaya ikan kerapu yang ia canangkan. Dalam kegiatan tersebut ia sempat memberikan arahan dan menyampaikan pesan bahwa program tersebut akan tetap berjalan meski ia tidak terpilih kembali sebagai Gubernur. Pada 6 Oktober 2016, seorang bernama Buni Yani mengunggah potongan video Ahok di kegiatan tersebut dengan menonjolkan pernyataan yang dikesankan mengandung unsur penistaan terhadap Islam. Buni Yani mengunggah video tersebut di laman Facebook-nya dengan judul yang provokatif: 'Penistaan terhadap Agama?'. Video tesrebut menyebar dan menyulut emosi kelompok Islam yang merasa kitab suci dan ulamanya dihina. Pada 10 Oktober 2016 secara resmi Ahok menyampaikan permintaan maaf kepada publik, namun tuntutan hukum tetap diajukan atas dugaan penistaan agama.

Adapun secara konteks, keterkaitan antara Aksi 2122016 dengan Reuni 212 pada 2 Desember 2018 adalah keduanya termasuk dalam payung kegiatan yang disebut sebagai Aksi Bela Islam. Pertama kali dilakukan pada 14 Oktober 2016, Aksi Bela Islam I dikomando oleh Front Pembela Islam (FPI) melakukan unjuk rasa seusai shalat Jumat di depan Balai Kota DKI Jakarta, menuntut agar penyelidikan atas kasus penistaan agama yang dilakukan oleh Gubernur DKI Jakarta segera dilakukan. Aksi ini dilaksanakan dalam beberapa kali momentum, yang dapat penulis ringkat sebagai berikut:

1. Aksi Bela Islam I (14 Oktober 2016): Dilaksanakan di depan Balai Kota DKI Jakarta.

2. Aksi Bela Islam II (4 November 2016): Disebut juga 'Aksi 4 November' atau 'Aksi Damai 411', dilaksanakan di depan
Istana Negara, peserta sejumlah 50.00200.000 orang. (bbcnews.com)

3. Aksi Bela Islam III (2 Desember 2016): Disebut juga 'Aksi 212', dilakukan di halaman Monas, Jakarta, setidaknya puluhan ribu massa berkumpul.

4. Aksi Bela Islam IV (11 Februari 2017): Disebut juga 'Aksi 11 Februari', dilaksanakan di Masjid Istiqlal Jakarta dengan kegiatan zikir dan tausiah.

5. Aksi Bela Islam V (21 Februari 2017): Berlangsung di depan kawasan Gedung DPR Senayan, Jakarta Pusat.

6. Aksi Bela Islam VI (31 Maret 2017): Disebut juga 'Aksi 313', dilaksanakan dengan melakukan long march dari Masjid Istiqlal menuju Istana Merdeka.

7. Aksi Bela Islam VIII (5 Mei 2017)

8. Reuni 212 । (2 Desember 2017): Dilaksanakan di Lapangan Monas untuk merayakan satu tahun Aksi 212.

9. Reuni 212 II (2 Desember 2018): Dilaksanakan di Lapangan Monas untuk merayakan 2 tahun Aksi 212.

Secara keseluruhan, kegiatan Reuni 212 pada 2 Desember 2018 berlangsung damai hingga peserta membubarkan diri secara tertib. Terlepas dari adanya perdebatan mengenai jumlah peserta yang hadir, menurut laporan kalkulasi Tirto (2018), peserta Reuni 212 memadati area dalam dan luar Monas dengan total jumlah peserta antara 80 - 120 ribu orang (https://tirto.id/ reuni-212-benarkah-klaim-8-juta-pesertadaTm).

\section{Peran Media Sosial dalam Mobilisasi Aksi 212}

Terlepas dari perdebatan berapa jumlah peserta yang hadir dalam aksi Reuni 212, yang jelas dapat diamati adalah bahwa aksi tersebut telah berkembang sejak pertama kali diselenggarakan pada 2 Desember 2016, apalagi jika dibandingkan dengan kegiatan paling pertama Aksi Bela Islam I pada 14 Oktober 2016. Dari aksi yang dilaksanakan hanya oleh ratusan hingga ribuan orang dan hanya diikuti oleh anggota Front Pembela Islam, aksi 212 menjadi aksi 
bersama kelompok Islam yang terbilang besar dan mampu menggerakkan masa setidaknya ratusan ribu orang dan berasal dari kelompok Islam di luar Front Pembela Islam.

Aksi Reuni 212 pada 2 Desember 2018 pun dapat disebut memiliki gaung di beberapa daerah di Indonesia. Beberapa media memberikan liputan mengenai banyaknya peserta yang datang dari daerah untuk mengikuti Reuni 212 di Jakarta. Contohnya dalam laporan Republika, terdapat seorang peserta Reuni 212 yang berasal dari Batam yang harus mengeluarkan biaya transportasi hingga akomodasi secara mandiri untuk mengikuti kegiatan tersebut di Jakarta. Selain itu ia juga mengaku bahwa ia datang dari Batam dan menyempatkan diri untuk datang ke Jakarta bersama 1.200 orang lain untuk mengikuti Reuni 212 (https://m.republika.co.id/amp/pj3ual383).

Berdasarkan gambaran tersebut terlihat bahwa 2 tahun sejak Aksi 212 yang pertama, peserta kegiatan tersebut tak lagi sama. Dari semula hanya diikuti oleh kelompok FPI, acara Reuni 212 memuat keikutsertaan kelompok Islam dari banyak golongan di luar FPI, bahkan hingga di luar Jakarta, Jabodetabek, dan Jawa. Hal ini menandai adanya proses komunikasi yang dilangsungkan oleh pihak-pihak dari lingkaran Aksi Bela Islam di periode awal kepada pihak-pihak lain sehingga aksiaksi yang diselenggarakan berikutnya dapat meluas dan diikuti oleh lebih banyak peserta.

Salah satu cara yang digunakan oleh anggota Aksi212 untukmengkomunikasikan aksi tersebut kepada pihak-pihak lain secara luas adalah melalui media sosial. Berdasarkan penelusuran penulis pada 18 Desember 2018 di 3 media sosial besar Facebook, Twitter, dan Instagram, masingmasing terdapat akun-akun dan post mengenai Aksi 212. Lebih lanjut, penulis menemukan bahwa komunikasi Aksi 212 di media sosial dilakukan oleh akun-akun Islami non-personal (akun komunitas atau fan page), yakni akun-akun yang secara umum mengunggah konten-konten ke-
Islam-an. Penulis tidak berhasil menemukan data angka pasti mengenai jumlahnya, namun akun-akun konten Islam ini di Twitter, Facebook, dan Instagram ini jumlahnya mencapai angka ratusan.

Sebagai gambaran, hashtag \#aks212 di Instagram memuat lebih dari 81.300 unggahan foto \& video. Di Facebook, terdapat 4 laman yang masing-masing bernama 'Aksi Damai 212', 'Alumni Aksi Damai 212', 'Info Aksi Bela Islam 212', dan 'Potret Aksi Bela Islam 212' dengan jumlah anggota penggemar terbanyak. Secara berurutan, masing-masing laman tersebut memiliki 4.600, 1.800, 3.200, dan 2.800 penggemar. Untuk di Twitter, terdapat akun @MuslimMudaID dengan nama profil '\#Belalslam' yang memiliki 4.929 pengikut, serta akun @Remajalslam212 dengan nama profil 'Aksi 212'memiliki 3.672 pengikut.

Akun-akun media sosial dengan fokus konten Aksi 212 di atas terbilang memiliki jangkauan khalayak yang cukup besar, mencapai ribuan dengan menghitung hanya dari jumlah pengikut dan penggemarnya. Namun perlu digarisbawahi bahwa setiap pengikut atau penggemar di setiap akun tersebut dapat membagikan (kontenkonten Retweet pada Twitter, Share pada Facebook) yang ada kepada masingmasing lingkarang akunnya, sehingga jumlah khalayak potensial dari akun-akun tersebut sifatnya eksponensial dari angka pengikut atau penggemarnya. Apabila diandaikan $10 \%$ dari pengikut akun dengan pengikut berjumlah 1000 ikut menyebarkan konten Aksi 212 dan menjangkau masingmasing 200 orang di lingkaran pribadinya, maka jangkauan khalayak akun tersebut sebenarnya adalah 20.000 orang. Hal ini belum mengasumsikan adanya re-Retweet dan re-Share, sehingga potensi jangkauan khalayak akun-akun Aksi 212 tersebut secara virtual tak terbatas (virtually limitless).

Selain potensi jangkauan khalayak akun-akun Islami pendukung Aksi 212 tersebut yang luas, jangkauan khalayak akun-akun tersebut juga secara geografis lintas daerah. Dalam artian, siapa saja dengan akses internet dapat mengakses 
unggahan konten akun tersebut. Sebagai contoh, akun \#Belalslam sangat bisa memiliki pengikut dari Jakarta, Jawa Timur, Aceh, hingga daerah-daerah di Kalimantan, Sulawesi, dan seterusnya. Hal ini salah satunya menjelaskan mengapa Aksi 212 bisa berkembang dengan meningkatnya jumlah peserta yang berasal dari lintas daerah, sebab mereka bisa memperoleh informasi mengenai Aksi 212 melalui media sosial secara mudah.

\section{Khalayak Twitter Reuni 212 sebagai Jejaring Komunitas Virtual}

Berdasarkan paparan konteks aksi Reuni 212 dan kekuatan media sosial dalam membantu mengembangkan jumlah peserta aksi tersebut, penulis menilai bahwa khalayak di lingkaran aksi Reuni 212 ini menarik untuk dikaji dalam kaitannya dengan Twitter sebagai media digital yang memfasilitasi komunikasi kelompok tersebut. Salah satu pertimbangan kemenarikan ini adalah fakta bahwasannya peserta Aksi 212 pada dasarnya adalah sebuah entitas komunitas di dunia fisik, yang kemudian dengan teknologi media digital terepresentasi di media sosial di mana mereka saling berkomunikasi. Paparan sebelumnya menjelaskan bahwasannya representasi komunitas di media sosial inilah yang melaksanakan fungsi komunikasi dalam menyebarluaskan ajakan Aksi 212, hingga pada gilirannya pesan komunikasi tersebut mampu tersebar luas dan menghasilkan peningkatan jumlah peserta aksi pada entitas fisiknya berupa Reuni 212.

Landasan teori yang dapat digunakan sebagai pendekatan untuk menjelaskan fenomena khalayak Twitter Reuni 212 sebagai sebuah komunitas adalah teori virtual community, salah satu teori khalayak aktif dalam kajian komunikasi media. Secara singkat, pencetus teori komunitas virtual Howard Rheingold (1993) mendefinisikan komunitas virtual sebagai "sekelompok orang yang mungkin atau mungkin tidak bertemu satu sama lain secara langsung, dan bertukar kata dan ide melalui mediasi papan buletin komputer dan jaringan." Hal ini sejalan dengan fenomena komunitas Aksi
212 di media sosial Facebook, Instagram maupun Twitter, bahwasannya mereka bertukar informasi, ide-ide dan pesan melalui medium jaringan internet media sosial tersebut mengenai aksi meskipun mereka terpisah secara geografis dan sebagian besar tak pernah bertemu secara langsung.

Komunitas Aksi 212 di media sosial ini juga menarik dari segi bagaimana mereka saling bekerjasama menyebarkan info-info mengenai aksi, sehingga terbilang cukup efektif apabila diukur dari kehadiran peserta yang bertambah dari tahun ke tahun. Pada gilirannya, proses kerjasama ini membentuk sebuah jejaring komunikasi antar akunakun Twitter dengan karakteristik tertentu. Jaringan adalah seperangkat aktor yang mempunyai relasi dengan aktor lain dalam tipe relasi tertentu; aktor yang dimaksud dapat berupa orang, lembaga, instansi, perusahaan, negara, dan sebagainya; sementara relasi yang dimaksud merujuk pada pola hubungan atau interaksi diantara aktor-aktor tersebut (Eriyanto, 2014).

\section{Apakah Reuni 212 Merupakan Aksi Politik?}

Pada dasarnya, pasca Aksi 212 tahun 2016 sejak Ahok yang menjadi tujuan aksi tersebut diproses secara hukum, aksi-aksi berikutnya seperti Reuni 212 tahun 2017 dan Reuni 212 tahun 2018 diklaim oleh panitianya sebagai murni aksi moral dan keagamaan (https://tiro.id/mengapa-reuni212-kian-lembek-daPA). Namun karena pada aksi di tahun 2018 ini bertepatan dengan momentum politik kampanye Calon Presiden dan Wakil Presiden untuk Pilpres di tahun 2019, aksi Reuni 212 ini banyak disangsikan oleh beberapa pihak akan mengarah sebagai aksi politik. Hal ini diindikasikan dari kecenderungan aksi tersebut yang hanya mengundang salah satu calon Presiden, yakni calon nomor urut 2 Prabowo Subianto, untuk hadir dan diberi kesempatan berpidato, sementara Presiden Joko Widodo yang merupakan calon Presiden nomor urut 1 tidak diundang untuk hadir termasuk pada Reuni 212 pertama di tahun 2017 (https://m.cnnindonesia.com/ reuni-aksi-212-dinilai-untuk-kepentinganpolitik). 
Oleh sebab itu, dikaitkan dengan fokus penelitian ini yang hendak mengkaji bagaimana dinamika komunitas virtual aksi Reuni 212 dalam mengkomunikasikan aksi tersebut di Twitter, maka penulis sekaligus hendak mengetahui apakah dalam pesanpesan yang saling dipertukarkan di Twitter juga terdapat muatan komunikasi politik. Tentunya, kampanye politik di Twitter tak dapat dilakukan secara bebas dengan menyebarluaskan informasi negatif atau serangan terhadap kandidat yang dioposisi, karena hal ini diatur oleh undang-undang di Indonesia. Hal ini diatur dalam UndangUndang Nomor 7 Tahun 2017 tentang Pemilihan Umum, yang mana pasal 280 ayat 1 huruf c menyebutkan bahwa "pelaksana, peserta, dan petugas kampanye dilarang menghinda seseorang, agam, suku, ras, golongan, calon dan/atau Peserta Pemilu yang lain." Undang-undang lain yang juga turutmeregulasi komunikasi di Twitter adalah Undang-Undang Nomor 11 Tahun 2018 tentang Informasi dan Transaksi Elektronik, yang pada pasal 27 ayat 3 melarang setiap orang untuk mendistribusikan informasi elektronik yang bermuatan "penghinaan dan/atau pencemaran nama baik."

Undang-undang yang mengatur proses komunikasi di Twitter tersebut sekaligus memberikan kewenangan bagi aparat Pemerintah untuk menindak orangorang yang melanggar hingga tuntutan hukum, atau pada tataran yang lain, menonaktifkan akun media sosial yang digunakan (take down) sebagai bentuk upaya sensor. Sebagai contoh, penulis pernah melakukan penelitian terhadap kampanye hitam di Twitter dengan tagar (hashtag) \#bapakhoaxnasional. Penelusuran pada 26 November 2018 mendapati 1814 tweet kampanye hitam pada rentang waktu 5 - 17 November 2018. Namun pada 1 Desember 2018, dengan penelusuran tagar yang sama, rentang waktu 5 - 30 November 2018 hanya menyisakan 397 tweets karena lebih dari 75\% di antaranya sudah ditindak, baik melalui reporting as spam maupun suspending account. Hal ini menggambarkan seberapa intensif proses penindakan terhadap aktor-aktor tidak etis dalam berkomunikasi politik di Twitter.

Adapun dari 3 alternatif media sosial Facebook, Twitter, dan Instagram, penulis memilih Twitter sebagai platform yang khalayak Aksi 212-nya akan dikaji. Pilihan ini jatuh berdasarkan pertimbangan 2 hal: (1) Twitter adalah media sosial yang akses untuk menggali atau crawling data kontenkontennya lebih mudah dan masih dalam jangkauan penulis, tidak membutuhkan keterampilan mahir seperti bahasa pemrograman R, dsb. Serta (2) tool untuk melakukan crawling data konten media sosial Twitter yang dapat dijangkau oleh penulis adalah Netlytic, namun Netlytic membatasi penggalian data Twitter per satu dataset hanya hingga 1000 tweet, sehingga angka ini menjadi batasan jumlah tweet yang dapat penulis gunakan untuk menganalisis komunitas virtual Aksi 212 di Twitter. Selain itu, Netlytic juga memiliki batasan hanya dapat menggali data tweet hingga 14 hari sebelum proses crawling data dilakukan.

Berangkat dari konteks Twitter yang kerap dengan tindakan pelaporan dan dapat berujung pada sensor, kelompok pendukung salah satu kandidat dituntut untuk bermain secara strategis dalam mengkomunikasikan pesan-pesan politiknya agar terhindar dari penindakan aparat berwenang, termasuk di Twitter. Salah satu strategi yang dapat dilakukan oleh para 'aktivis' pendukung salah satu kandidat ini adalah dengan melakukan digital masquerading, yakni aksi aktivisme digital yang merekayasa dan mengkonstruksi pesan dalam komunikasi sosial-politik digital untuk menghindari ancaman sensor dari pihak yang berwenang (Tan, 2017). Berdasarkan paparan latar belakang masalah di atas, maka penulis menetapkan 2 rumusan masalah yang menjadi fokus research paper ini adalah bagaimana karakteristik khalayak Twitter aksi Reuni 212 tahun 2018 sebagai sebuah jaringan komunikasi virtual community? Apakah terdapat upaya digital masquerading yang dilakukan oleh aktoraktor komunikasi Reuni 212 tahun 2018 di Twitter? 


\section{B. TELAAH PUSTAKA}

\section{Twitter dan Virtual Community}

Virtual community adalah salah satu teori perspektif khlayak media aktif. Istilah 'virtual community atau 'komunitas virtual' ditemukan oleh ahli teori Howard Rheingold, yang mendefinisikannya sebagai: "Sekelompok orang yang mungkin atau mungkin tidak bertemu satu sama lain secara langsung, dan yang bertukar kata dan ide melalui mediasi papan buletin komputer dan jaringan. Di dunia maya... kita melakukan semua hal yang dilakukan orang ketika orang berkumpul, tetapi kami melakukannya dengan kata-kata di layar komputer, meninggalkan tubuh kami di belakang" (Rheingold, 1993) (Long \& Wall, 2013). Komunitas virtual di internet memiliki ciri utama etos berbagi yang memungkinkan internet untuk tumbuh ke tingkat yang spektakuler, sebab internet memungkinkan khalayak aktif untuk menghasilkan materi dan makna, dan untuk berinteraksi satu sama lain dan mendirikan produksi media profesional hingga pada tingkat yang tak terbayangkan di masa lalu.

Anggota komunitas virtual memiliki kode etik dan etika yang berasal dari interaksi 'kehidupan nyata' untuk membuat lingkungan sosial yang baik. Mereka memiliki seperangkat aturan sendiri agar berfungsi dengan benar. Di sinilah istilah 'netiquette' berasal. Netiquette mengacu pada etiket online, aturan yang diterima secara umum, dan cara berkomunikasi di ruang virtual. Penggunaannya mencerminkan struktur nilai dan keyakinan dari masyarakat 'nyata' dan mampu memperkuat hubungan kekuasaan dan ketidaksetaraan yang ada dengan cara yang sama seperti bentuk kelembagaan lainnya.

Komunitas virtual juga disadari sering secara aktif dimoderasi sehingga dapat mencegah spam dan posting topik atau komentar yang tidak diinginkan. Karena itu, moderator mengambil peran 'gatekeeper', memutuskan apa yang dapat dan tidak dapat diterima. Pengambilan keputusan ini tunduk pada nilai-nilai dan keyakinan pribadi moderator. Penelitian Ananda Mitra pada kelompok komunitas soc.culture.indian, di mana dia memeriksa postingannya. la menemukan bahwa, meskipun banyak anggota komunitas berpartisipasi secara aktif dengan menanggapi pesan, sebagian besar pengguna membaca tetapi tidak memberikan tanggapan. Orang-orang ini diidentifikasi sebagai 'pengintai' (lurkers) (Mitra, 1997: 62).

Twitter merupakan layanan jejaring sosial dan microblogging yang didirikan oleh Biz Stone, Evan Williams, dan Jack Dorsey pada tahun 2006. Media sosial ini memungkinkan penggunanya untuk mengirim dan membaca pesan berbasis teks hingga 280 karakter, yang dikenal dengan sebutan kicauan (Tweet). Twitter digunakan untuk berbagai komunikasi dan penyebaran informasi. Fungsinya sederhana, dapat menyebarkan informasi dengan mudah dan cepat, serta memiliki tata bahasa deskriptif yang menjadi ciri khas dari media sosial ini, yang tercermin melalui beberapa fitur berikut:

1. Retweet: Merupakan fitur pada Twitter untuk membagi atau mengunggah ulang sebuah kicauan dari orang lain agar dapat dilihat oleh semua followers. Fitur Retweet biasanya disimbolkan dengan tanda arah panah bolak-balik (reversible) di bagian bawah kicauan. Ada dua pilihan retweet yang dapat dilakukan, yakni "Retweet" dan "Retweet with comment". Fitur "Retweet with comment" digunakan jika pengguna ingin menambahkan komentar dari kicauan asli yang ingin dibagikan, sementara fitur "Retweet" digunakan jika ingin langsung membagikan kicauan tanpa mengubah atau memberi komentar.

2. Hashtag: Merupakan kata tanpa spasi yang diawali dengan tanda "\#". Hashtag atau tagar (tanda pagar), dapat berupa kalimat maupun akronim. Fungsi tagar adalah jika kita tertarik terhadap suatu isu, maka tagar dapat membantu melacak semua orang yang berbicara tentang hal itu. Penyebutan tagar yang sedang paling sering muncul dalam 
kicauan dapat membuat tagar tersebut menjadi populer (trending topic).

3. Mention: Penyebutan username pengguna Twitter lain pada sebuah kicauan yang dapat dilihat oleh followers masing-masing. Mention adalah sebuah fitur yang membantu pengguna untuk terlibat dalam sebuah interaksi di Twitter di mana semua pesan bersifat publik. Dalam percakapan, orang tidak hanya mengatakan sesuatu, mereka mengatakan hal-hal secara khusus satu sama lain, fitur mention berguna untuk mengetahui pesan mana yang ditujukan khusus untuk seseorang.

4. Reply: Merupakan balasan dari kicauan publik yang ditujukan pada pembuat kicauan tersebut. Fitur reply dimaksudkan untuk menjadi percakapan. Perbedaan antara reply dan mention terletak pada kicauan pertama yang menginisiasi adanya interaksi. Saat ini Twitter sudah menambahkan fitur reply dengan memberitahu pengguna jika seseorang me-reply sebuah kicauan dengan memberi keterangan "Replying to (username)".

5. Timeline: Merupakan beranda dari Twitter yang berisi daftar kicauan dari akun yang telah di-follow. Timeline menampilkan kicauan berdasarkan urutan algoritma relevansi kicauan yang sedang populer dalam suatu waktu, sehingga kicauan teratas belum tentu kicauan yang paling baru diposting. Hal ini memudahkan untuk mengikuti topik yang sedang tren atau yang sedang hangat diperbincangkan di Twitter.

6. Following dan Followers: Following merupakan daftar akun yang diikuti oleh pengguna. Dengan mengikuti sebuah akun, maka pengguna akan menerima kicauan terkini (up-to-date) dari akunakun yang diikuti. Sedangkan Followers adalah daftar akun yang mengikuti pengguna, serta dapat melihat profil dan menerima kicauan terkini dari pengguna tersebut.

7. Like: Adalah fitur yang memungkinan seorang pengguna untuk 'menyukai' kicauan pengguna lain, ditandai dengan ikon hati. Ketika seorang pengguna menyukai sebuah kicauan, maka kicauan tersebut akan muncul di timeline milik followers pengguna yang menyukai tersebut sebagai aktivitas, bukan sebagai mekanisme sharing seperti retweet.

\section{Jaringan Komunikasi}

Jaringan komunikasi adalah pola kontak yang terbentuk dari mengalirnya pesan di antara komunikator melalui ruang dan waktu (Monge dan Contractor, 2003). Ketika manusia berkomunikasi dengan manusia lainnya, mata rantai (link) terbentuk (Weick, 1979 dalam Littlejohn dan Foss, 2005). Komunikasi selalu menyertakan hubungan (relationship) sebab komunikasi adalah selalu sebuah kejadian bersamasama, juga sebuah proses bersamaan dari suatu pembagian (sharing) informasi antara dua orang atau lebih (Monge \& Contractor, 2003).

Metode analisis jaringan komunikasi dapat didefinisikan sebagai metode yang berusahamenggambarkan dan menjelaskan jaringan sosial dan struktur jaringan. Dalam hal ini jaringan dapat didefinisikan seara sederhana sebagai seperangkat aktor yang memiliki relasi dengan aktor lain dalam tipe relasi tertentu. Analisis jaringan komunikasi menggambarkan relasi aktor satu dengan lainnya dalam struktur sosial tertentu. Terdapat 2 kata kunci utama jaringan komunikasi: (1) Aktor, di mana jaringan komunikasi melihat fenomena peristiwa dari sisi mikro (aktor), bukan makro, dan (2) relasi, yakni bagaimana aktor-aktor berinteraksi satu sama lain (Eriyanto, 2014).

Secara garis besar, jaringan merepresentasikan hubungan ikatan di antara seperangkat aktor yang disebut nodes. Nodes bisa manusia, kelompokkelompok, organisasi atau lainnya. Hubungan, disebut edge, yang terjadi bisa komunikasi, pengaruh, berbagi interpretasi, atau transfer sumber daya tangible. Hubungan dapat bersifat directional atau non-directional, binary atau valued, dan uniplex atau multiplex. Jaringan ini dapat 
digambarkan melalui matriks dan grafik (Monge dan Contractor, 2003).

\section{Digital Masquerading}

Terjemahan secara bahasa dari digital masquerading adalah penyamaran digital. To masquerade pada umumnya dipahami sebagai proses berpura-pura menjadi seseorang yang bukan aslinya (to pretend to be someone one is not). Gagasan digital masquerading diuraikan sebagai aksi bagaimana aktivis secara taktis menggunakan media dan dengan hati-hati mengatur agenda mereka, dan dengan tingkat kesadaran diri yang tinggi tentang kemungkinan kriminalisasi dan agensi kuat yang bernegosiasi dengan pengawasan ketat negara, sehingga dilakukan langkahlangkah penyamaran dalam kampanye digital mereka, atau digital masquerading (Tan, 2017).

Dalam penelitan Jia Tan yang mengeksplorasi praktik-praktik digital masquerading yang dilakukan oleh Youth Feminist Action School (YSAF), ia berpendapat bahwa peran media dalam gelombang baru aktivisme media oleh feminis terwujud dalam tiga cara. Pertama, terdapat kesadaran diri dan agen aktivisme dalam penggunaan media secara taktis untuk menghindari sensor, sebuah praktik media yang secara khusus mengatur agenda media, meningkatkan pengaruh publik, dan menghindari penyensoran. Kedua, adanya penggubahan (editing) konten, dalam hal ini foto, digital untuk secara taktis mewakili representasi yang diinginkan di ruang publik sambal tetap berusaha menghindari sensor dan kriminalisasi yang mungkin terjadi. Ketiga, gagasan tentang digital masquerading merujuk pada antarmuka media dan subjek, yang melibatkan upaya kolektif dalam merangkai kegiatan-kegiatan aktivis dan membangun kembali publisitas.

\section{Model Operasionalisasi Konseptual}

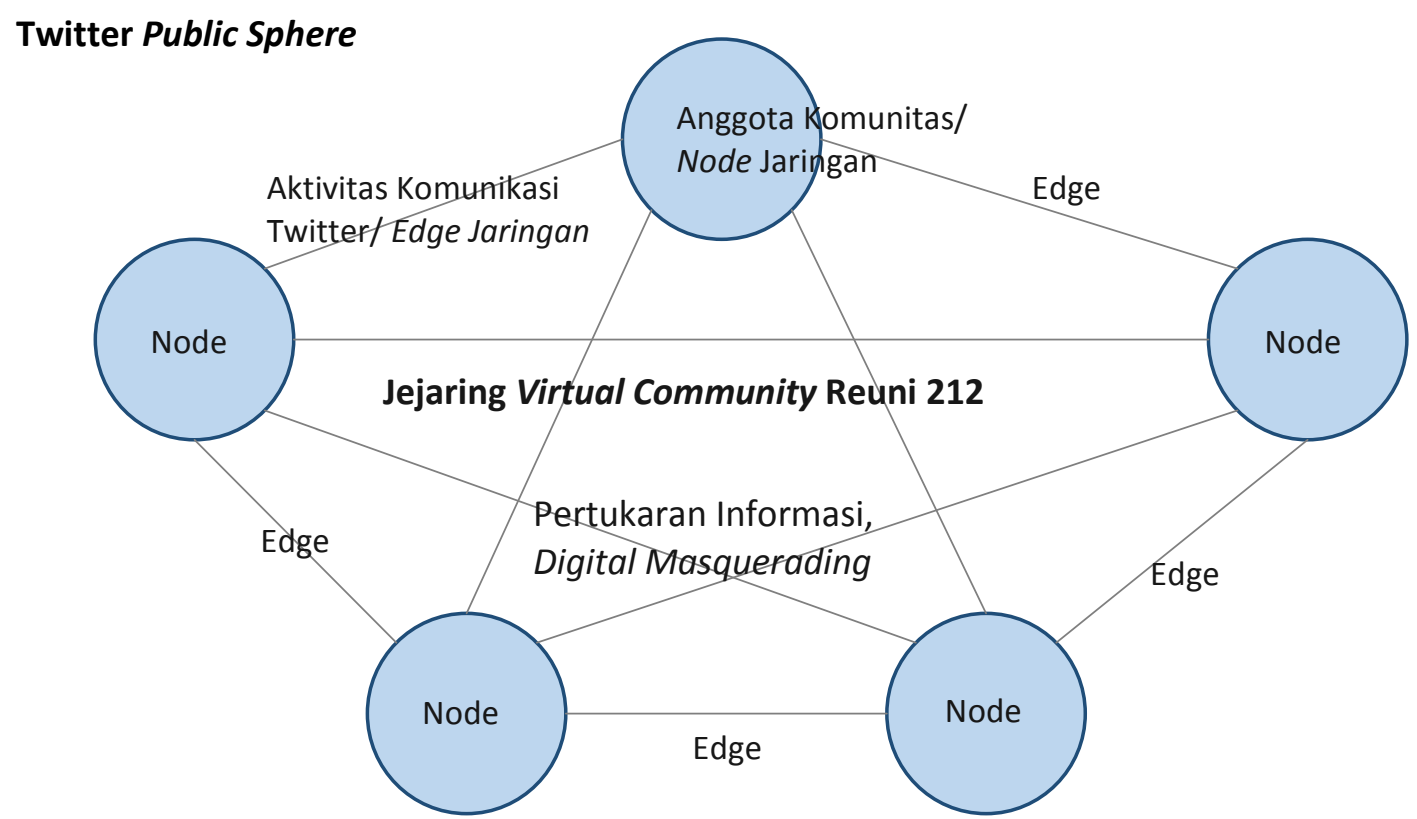

Gambar 1 - Model Kerangka Konseptual

Berdasarkan teori virtual community, jaringan komunikasi, dan Twitter yang telah dipaparkan, aktivitas komunikasi komunitas virtual dapat terjadi di media digital, yang dalam konteks penelitian ini adalah Twitter, dan terhubung satu sama lain membentuk sebuah jaringan komunikasi. Pada praktiknya, komunikasi komunitas virtual 
dimungkinkan dilakukan dalam kicauan yang diunggah oleh seseorang yang memiliki akun Twitter. Kicauan tersebut dapat secara langsung memuat informasi mengenai topik Reuni 212 secara lisan/ verbal serta muatan digital masquerading atau tidak. Dengan adanya fitur mention pada Twitter, kicauan topik Reuni 212 dimungkinkan untuk menyertakan mention, atau memanggil seseorang yang memiliki akun Twitter. Apabila orang yang dituju tersebut tidak memiliki akun Twitter, maka sebuah mention "@namapengguna" tidak akan memanggil dan memberi notifikasi pengguna yang disasar.

Berikutnya, kicauan topik Reuni 212 dapat direspon secara interaktif melalui beberapa fitur Twitter yakni Retweet, Reply, dan Like. Ketika seorang pengguna meretweet sebuah kicauan topik Reuni 212, maka pengguna tersebut akan membagikan kicauan tersebut kepada seluruh pengikutnya di Twitter. Setiap pengikut yang mendapatkan retweet tersebut dapat merespon kembali sebagaimana fitur respon yang dimungkinkan pada tweet pertama, yakni Retweet, Like, dan Reply. Demikian seterusnya proses interaksi respon di Twitter berlangsung secara berantai. Di sisi lain, ketika seorang pengguna menyukai (like) sebuah kicauan topik Reuni 212, maka aktivitas like tersebut akan muncul di timeline para pengikut pengguna tersebut, tetapi dengan tanda bukan sebagai retweet. Meski demikian, pengikut tetap dapat secara berantai bereaksi terhadap kicauan yang disukai tersebut dengan respon Retweet, Like, maupun Reply, meskipun kicauan tersebut tidak ditujukan untuk dibagikan. Sedangkan pada fitur Reply, seorang pengguna Twitter dapat membalas sebuah kicauan topik Reuni 212 dengan sebuah kicauan balasan, dan ditampilkan di bawah kicauan topik Reuni 212.

Dengan demikian, identifikasi aktor (node) dan relasi (edge) pada jaringan komunikasi virtual community Reuni 212 di media sosial Twitter dapat dianalisis sebagai berikut: node atau aktor anggota komunitas virtual adalah pengguna Twitter, yang diidentifikasi melalui username (@ username), sedangkan edge atau relasi aktor-aktor tersebut dapat dianalisis dari relasi yang terbentuk melalui aktivitas kicauan topik Reuni 212, meliputi aktivitas mention, retweet, reply, dan like. Sementara analisis terhadap ada atau tidaknya praktik digital masquerading dilakukan terhadap analisis isi dan aktivitas komunikasi Twitter secara menyeluruh.

\section{METODE PENELITIAN}

Untuk mengetahui secara umum pola struktur komunikasi dalam jejaring komunikasi komunitas virtual khalayak Twitter aksi Reuni 212, dalam penelitian ini dilakukan analisis jaringan komunikasi, yaitu metode yang berusaha menggambarkan dan menjelaskan jaringan sosial dan struktur jaringan (Eriyanto, 2014). Oleh sebab itu, penulis akan melaksanakan proses analisis jaringan komunikasi sederhana dari data yang berhasil dikumpulkan dari Twitter. Yang dimaksud analisis sederhana di sini adalah penulis hanya menggunakan metode analisis jaringan sebatas untuk mengetahui struktur jaringan komunikasi yang terjadi, bukan analisis jaringan komunikasi secara utuh, serta menemukan aktor-aktor utama (pusat konsentrasi) dalam jaringan komunikasi komunitas virtual aksi Reuni 212.

Penelitian ini menggunakan data dokumen elektronik berupa arsip tweettweet dari Twitter. Pengumpulan data dilakukan dengan menggunakan Netlytic, aplikasi analisis jaringan media sosial berbasis web yang beralamat di netlytic.org. Data Twitter tersebut kemudian diolah dan dilakukan proses analisis serta visualisasi jaringan komunikasi menggunakan software Gephi, yakni software yang memiliki spesialisasi dalam pengolahan data yang bersifat jaringan.

Dalam rangka menelusuri data khalayak aksi Reuni 212 di media sosial Twitter pada momentum hari-H di tanggal 2 Desember 2018, penulis menggunakan tagar \#ReuniAkbar212 yang diakses pada hari pelaksanaan kegiatan tersebut. Tagar ini dipilih karena merupakan satu-satunya 
tagar yang sempat menjadi Trending Topic di Twitter Indonesia pada hari tersebut, sehingga diharapkan dapat mengjangkau khalayak Twitter secara lebih luas dan beragam. Keseluruhan tweet yang termasuk dalam tagar \#ReuniAkbar212 tersebut adalah populasi penelitian data penelitian, namun penulis mengambil sejumlah 1000 tweet sebagai sampel karena keterbatasan software Netlytic yang bebas akses.

Pada fitur Twitter, terdapat 2 jenis aktivitas yang berbeda signifikan, yakni aktivitas mention dan reply. Aktivitas mention adalah kegiatan memanggil pengguna lain dalam sebuah tweet dengan cara menulis nama pengguna (@username) akun tersebut, sehingga pengguna yang dipanggil mendapat pemberitahuan terlibat dalam sebuah komunikasi. Aktivitas retweet juga termasuk dalam aktivitas mention, sebab dalam proses retweet, seorang pengguna otomatis akan memanggil nama pengguna yang tweet-nya ia retweet di depan dan diikuti dengan kutipan tweet yang ia retweet.

Sedangkan aktivitas reply yakni kegiatan membalas pesan tweet pengguna Twitter lain dengan pesan baru yang disusun. Berbeda dengan aktivitas retweet yang cenderung pasif karena pengguna hanya membagikan kembali pesan dari pengguna lain yang sudah ada, aktivitas reply adalah sebuah kegiatan komunikasi aktif karena untuk menjawab tweet dari pengguna lain, seorang pengguna harus memproduksi pesan baru dan secara aktif menyusun dan mengetik pesan tersebut.

Oleh sebab itu, dalam analisis jaringan komunikasi dalam penelitian ini akan dibedakan antara jaringan komunikasi Twitter dari aktivitas mention dan aktivitas reply. Masing-masing dari jaringan tersebut memiliki jumlah nodes (aktor) dan edges (relasi komunikasi) masing-masing.

\section{HASIL DAN PEMBAHASAN}

\section{Temuan Data dan Analisis Jaringan Komunikasi}

Berikut ini adalah overview data yang berhasil ditemukan:

\begin{aligned} & \hline Jumlah Data Tweet 1000 \\ & \hline Rentang Tanggal 2 Desember 2018 \\ & Tweet (1 Hari) \\ & \hline Rentang Jam Tweet $18: 12-18.59$ WIB \\ & \hline Mentions: Jumlah 200 \\ & Node \\ & \hline Mentions: Jumlah 355 \\ & Edges \\ & \hline Mentions: Aktor @prabowo, @ \\ & Sentral champbrb, @ \\ & marierteman \& @alex_ \\ & wu (nodes berimpitan) \\ & @kapitraampera \& @ \\ & ayahsidi77 (nodes \\ & berimpitan), @yan_ \\ & tanuwidjaya \end{aligned}

Replies: Jumlah 63

Node

Replies: Jumlah 64 Edges

Replies: Aktor @champbrb @yan_ Sentral tanuwidjaya

Hasil visualisasi jaringan komunikasi Mentions dan Replies Twitter adalah sebagai berikut: 


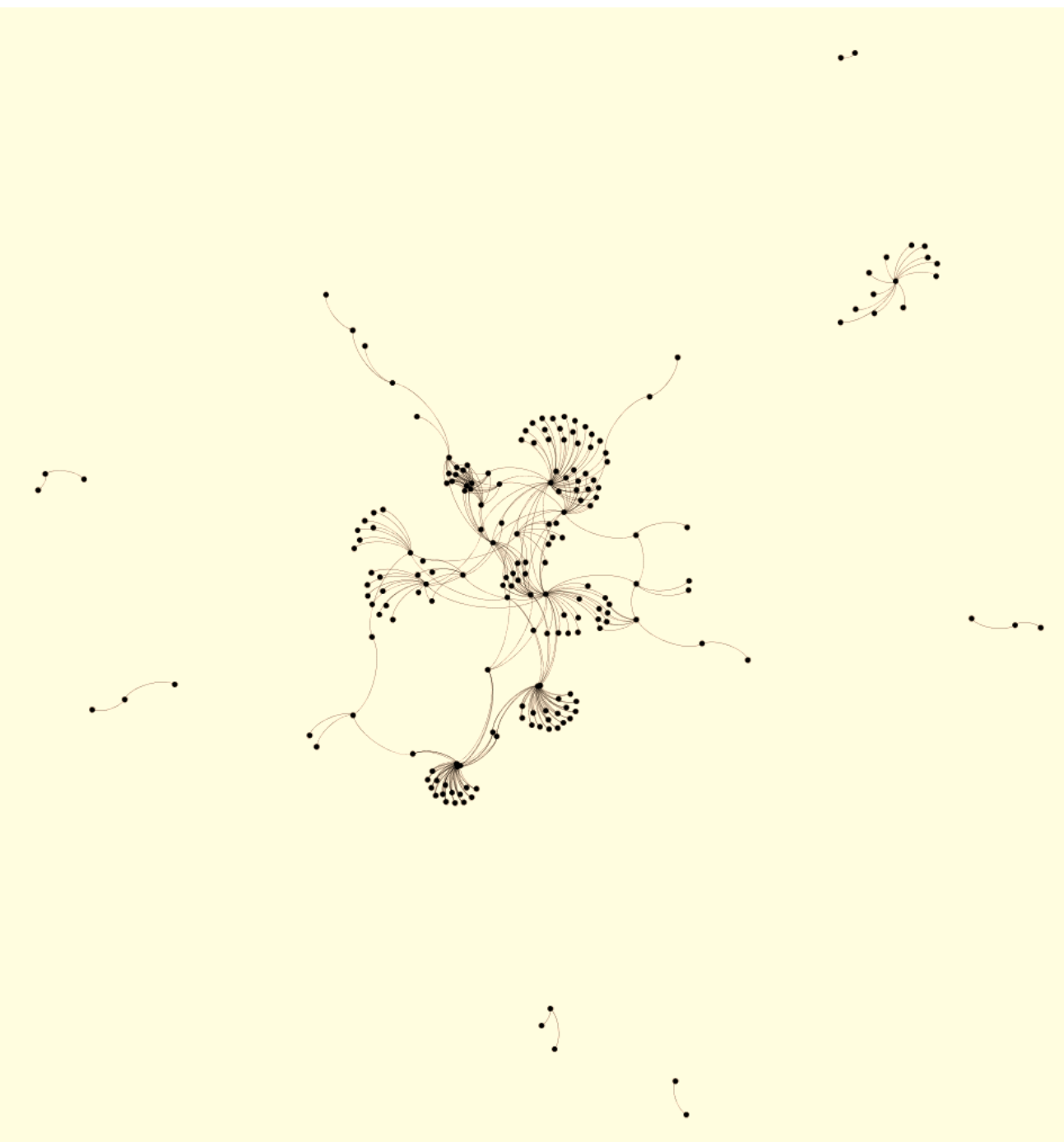

Gambar 2 - Sosiogram 1: Jaringan Komunikasi Mentions

Sosiogram 1 di atas menunjukkan adanya kecenderungan konsentrasi pada jaringan komunikasi mention Twitter pada tagar \#ReuniAkbar212 pada 2 Desember 2018. Jaringan terdiri dari 200 nodes dan membentu 355 edges. Konsentrasi jaringan tersebut menunjukkan adanya aktor-aktor, dalam hal ini adalah akun Twitter, dalam jaringan tagar tersebut yang cenderung lebih sering disebut (mentioned) daripada aktor-aktor yang lain. Ketika penulis telusuri, keterpusatan jaringan pada bagian tengah struktur merujuk pada aktor-aktor berikut (berurutan dari yang paling sering sering di-mention): @prabowo, @champbrb, @marierteman \& @alex_wu (nodes berimpitan)@kapitraampera \& @ayahsidi77 (nodes berimpitan). Sedangkan kelompok terpisah/klaster di luar pemusatan jaringan utama paling banyak merujuk pada mention nama pengguna@yan_tanuwidjaya.Adanya konsentrasi jaringan mention pada akun @ prabowo ini dapat menjadi salah satu faktor yang patut dipertimbangkan terhadap analisis dugaan bahwa khalayak komunitas virtual ini sedang melakukan aktivitas komunikasi kampanye politik, sebabakun @ prabowo adalah akun milik salah satu calon Presiden dengan nomor urut 2. 

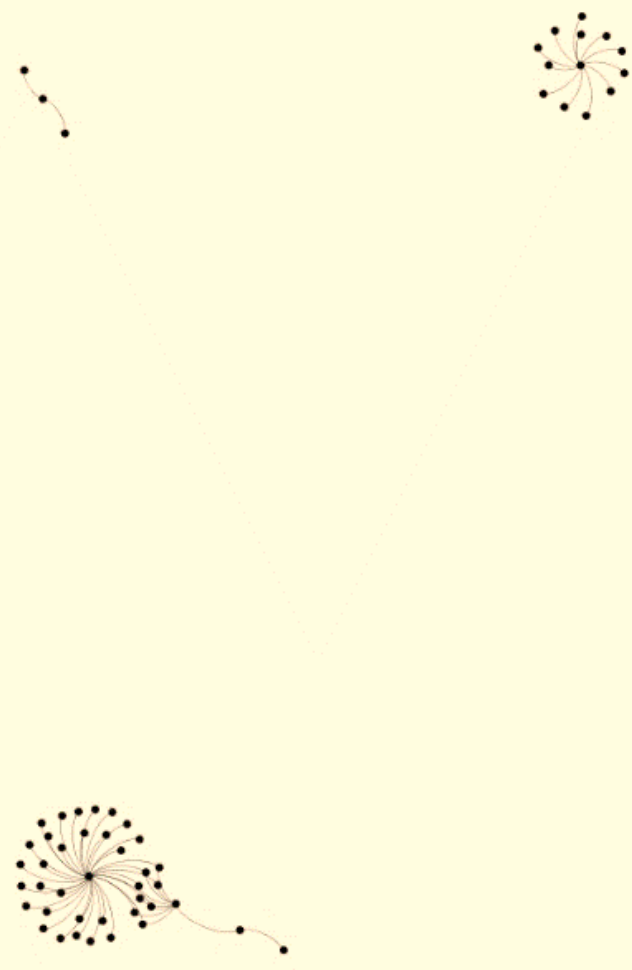

Gambar 3 - Sosiogram 2; Jaringan Komunikasi Replies

Berbeda dengan sosiogram 1, sosiogram 2 yang merupakan visualisasi jaringan komunikasi replies di atas tidak menunjukkan adanya pemusatan secara struktur. Jaringan terdiri dari 63 nodes membentuk 65 edges, sehingga dapat dikatakan bahwa masing-masing nodes yang ada tidak banyak membentuk relasi dengan nodes yang lain. Hal ini dapat diartikan bahwa jejaring komunikasi replies pada tagar \#ReuniAkbar212 tidak terhubung secara utuh dalam struktur, namun membentuk klaster-klaster jaringan. Masing-masing dari klaster terbesar pada sosiogram 1 berpusat pada aktor pengguna dengan nama @champbrb dan @yan_ tanuwidjaya.

Di luar dari masing-masing analisis terhadap kedua sosiogram di atas, ditemukan pada nama pengguna @ champbrb@yan_tanuwidjaya adalah dua nodes yang menjadi titik pemusatan kelompok baik pada jaringan komunikasi mention maupun replies dalam tagar \#ReuniAkbar212. Hal ini menunjukkan bahwa pengguna tersebut menjadi rujukan yang paling tinggi oleh akun-akun pengguna Twitter lain baik melalui mention maupun replies. Ketika penulis buka profil Twitter akun @yan_tanuwidjaya, memang secara jumlah followers dan tweets cukup banyak, yakni 1360 dan 15.670, sehingga cukup mengindikasikan secara permukaan bahwa jangkauan khalayak tweet-nya cukup luas (ribuan) dan merupakan pengguna Twitter yang aktif (jumlah tweet belasan ribu), sehingga menjadi akun nodes yang cukup menjadi pusat konsentrasi. 


\section{Analisis Virtual Community}

Merujuk pada definisi Howard Rheingold bahwa sebuah komunitas virtual adalah sekelompok orang yang melangsungkan aktivitas komunikasi melalui mediasi computer dan jaringan, penulis menemukan bahwa data-data tweet dengan tagar \#ReuniAkbar212 yang pada pada 2 Desember 2018 pukul 18.12-1859 WIB adalah sebuah realitas komunitas virtual. Hal ini berangkat dari asumi bahwa masing-masing akun Twitter dengan nama penggunanya yang unik adalah representasi individu atau orang-orang, kemudian dengan dimediasi Twitter melakukan aktivitas komunikasi. Dari 1000 data tweet yang penulis temukan, setidaknya aktivitas komunikasi di dalam Twitter yang terjadi adalah tweeting (membuat unggahan pernyataan baru secara mandiri), retweeting (menyalin ulang unggahan pernyataan pengguna lain untuk dibagikan kepada khalayak/pengikut personal), mentioning (memanggil pengguna lain dalam sebuah unggahan pernyataan), dan replying (membalas pernyataan pengguna lain dengan pernyataan diri sendiri).

Masing-masing aktivitas Twitter tersebut merupakan sebuah aktivas komunikasi yang dimediasi oleh komputer jaringan media Twitter. Sebagai contoh, hal ini dicerminkan oleh sosiogram 1 yang menggambarkan adanya pemusatan pemanggilan (mention) antara satu pengguna dengan pengguna lain. Pemusatan jaringan mention menunjukkan bahwa para pengguna yang dekat dengan konsentrasi mention tersebut adalah para pengguna yang berpartisipasi dalam aktivitas perujukan seorang subyek komunikasi. Sedangkan pada sosiogram 2 menurut penulis justru mencerminkan fenomena komunikasi yang lebih interaktif, meskipun pemusatan jaringannya tidak sepadat sosiogram 1. Pada sosiogram 2, klaster atau kelompok terbesar terpusat pada akun pengguna dengan nama @ champbrb, menandakan bahwa terdapat beberapa pengguna lain sebagai aktor komunikasi yang menjawab pesan yang sempat diutarakan oleh @champbrb dan membalas dengan tweet-tweet balasan.
Penulis sebut bahwa mekanisme replies Twitter lebih interaktif daripada mention, adalah karena pada mention mayoritas didominasi oleh aktivitas retweet (yang mana pasti memuat pemanggilan atau mention pengguna yang tweet-nya diretweet), sedangkan pada mekanisme reply, seorang pengguna harus menyusun pesan tertentu untuk membalas pesan pengguna yang di-reply.

Aspek lain dari komunitas virtual Twitter yakni adanya etos berbagi juga tercermin daridatatweet\#ReuniAkbar212yang penulis temukan. Hal ini cukup mudah diidentifikasi salah satunya dengan melihat jumlah total retweet sebagai mekanisme berbagi tweet antar pengguna. Penulis menemukan bahwa 93\% tweet yang dianalisis adalah berupa retweet, dengan jumlah persis 932. Hal ini menandakan bahwa mayoritas pengguna Twitter yang termasuk dalam jaringan tagar \#ReuniAkbar212, dan dalam batasan waktu yang penulis teliti, lebih memilih untuk meneruskan pesan atau tweet pengguna lain daripada menyusun tweet sendiri. Meski demikian, hal ini menjadi salah satu ciri yang selaras dengan teori virtual community yang menyatakan bahwa budaya komunitas virtual adalah adanya etos berbagi.

Selain menandakan budaya berbagi, tingginya jumlah retweet daripada aktivitas menyusun tweet sendiri merupakan salah satu contoh bahwa mayoritas pengguna Twitter pada batasan waktu dan data yang penulis teliti adalah pengguna yang pasif. Hal ini dikarenakan aktivitas retweet adalah aktivitas yang cenderung pasif karena pengguna Twitter tidak melewati aktivitas penyusunan pesan untuk komunikasi. Dalam istilah Ananda Mitra, para anggota komunitas virtual yang pasif ini disebut sebagai lurkers atau pengintai. Rendahnya pengguna Twitter yang benar-benar aktif berpartisipasi juga sejalan dengan temuan Mitra pada penelitian di soc.culture.indian. Meski demikian, penulis tidak dapat menilai apakah anggota komunitas virtual Twitter yang pasif ini berdampak negatif atau positif bagi komunitas itu sendiri, sebab data yang penulis amati masih cenderung terbatas. 
Tingginya jumlah retweet yang menandakan tingginya jumlah pengguna pasif, menunjukkan angka sebaliknya pada jumlah pengguna aktif, yakni sangat rendah, bahkan kurang dari $7 \%$ atau 78 pengguna. Namun, hal ini dapat diarahkan pada analisis identifikasi gatekeeper. Pengguna-pengguna Twitter yang aktif memproduksi pesan untuk di-retweet dalam jaringan adalah para aktor komunikasi yang menentukan pesan apa yang akan didistribusikan ke dalam jaringan, dan pada gilirannya memungkinkan untuk menjadi agenda komunikasi dalam jaringan tersebut. Dalam teori virtual community juga dikenal konsep gatekeeper, yakni aktor yang mengambil peran menentukan apa yang dapat dan tidak dapat diterima dalam komunitas virtual. Namun penulis menyadari bahwa gatekeeper dalam konteks 1000 data ini bukanlah gatekeeper yang sesungguhnya, sebab tidak ada kesepakatan atau ketundukan anggota komunitas virtual untuk menujuk, menerim, dan mematuhi salah satu aktor untuk bertindak sebagai penentu konten komunikasi di dalam komunitas virtual.

Analisis terakhir adalah mengenai etiket komunitas virtual. Penulis tidak banyak menemukan indikasi adanya etiket yang unik dari 1000 data Twitter yang penulis temukan. Namun paling tidak penulis membaca pola netiquette secara umum, yakni penghindaran penggunaan huruf kapital dalam menulis Twitter karena dapat melambangkan teriakan dan kesan membentak. Dari 1000 tweet yang penulis eksplorasi, tidak ada tweet yang menggunakan huruf-huruf kapital di mayoritas kalimatnya, sehingga menandakan bahwa para anggota komunitas virtual tersebut setidaknya memiliki ketundukan pada etiket untuk tidak menggunakan huruf-huruf kapital yang memandakan kalimat teriakan.

\section{Analisis Digital Masquerading}

Analisis digital masquerading berupaya untuk menemukan apakah terdapat taktik-taktik atau siasat yang digunakan anggota komunitas virtual aksi Reuni 212 dalam menghindari pelanggaran regulasi komunikasi elektronik dan pelanggaran kampanye. Proses ini penulis laksanakan dengan cara melakukan screening terhadap 1000 data tweet yang berhasil dikumpulkan, kemudian melakukan klasifikasi topik untuk dilakukan analisis isi. Hasil klasifikasi tweettweet tersebut yakni sebagai berikut:

\section{Klasifikasi Tweet Berdasarkan Topiknya}

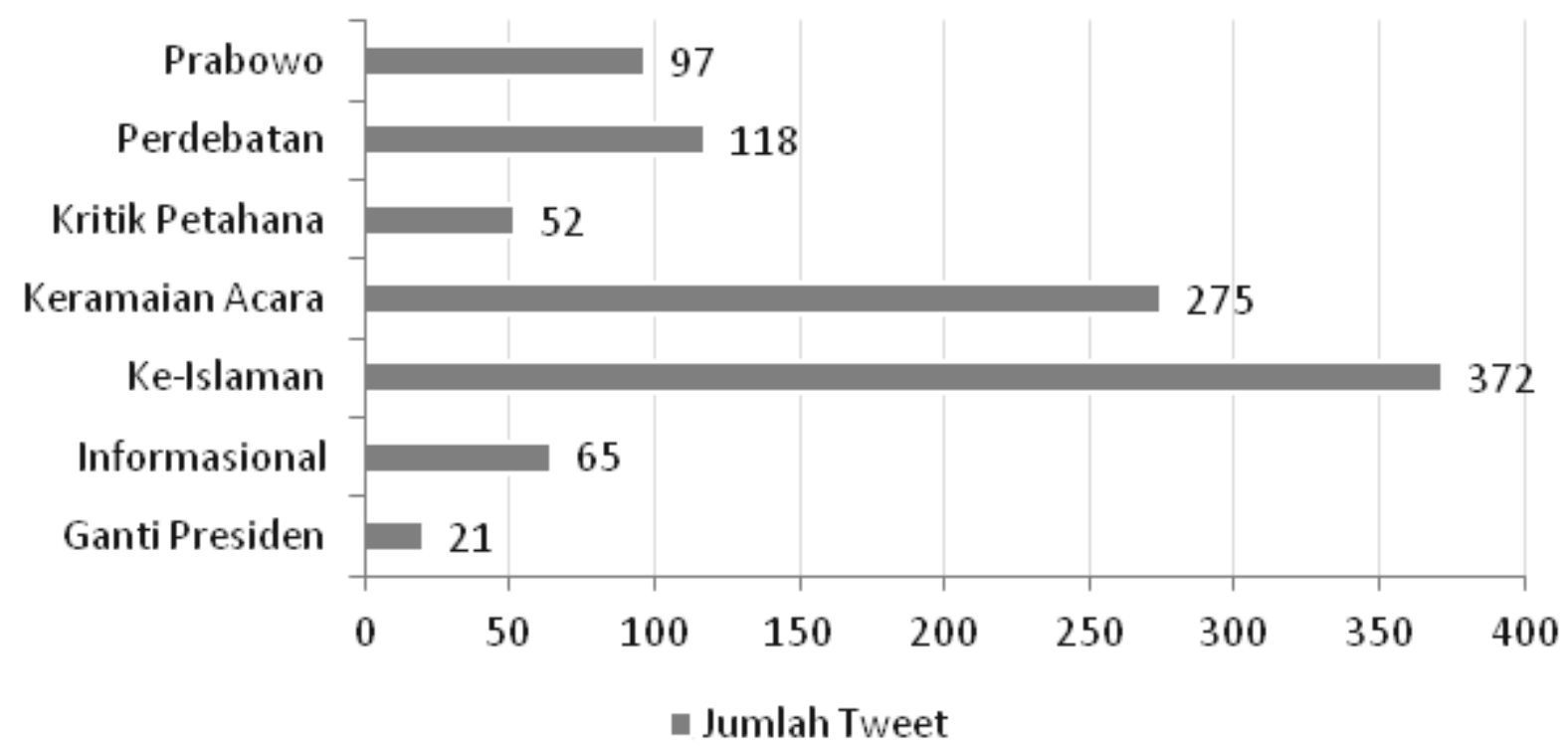

Gambar 4. Klasifikasi Tweet 
Untuk lebih menggambarkan bagaimana konten pesan dari masingmasing topik tersebut, berikut ini beberapa

kutipan tweet mewakili masing-masing topik:

Tabel 1. Topik Tweet

\begin{tabular}{|c|c|}
\hline Topik & Contoh Kutipan Tweet \\
\hline Ganti Presiden & $\begin{array}{l}\text { @putrabanten80: "Panik panik ada yang panik Ada yang panik Ganti } \\
\text { Presiden...2019 Ganti Presiden, Presiden kita...Prabowo-Sandi" Semangaaaatt } \\
\text { \#2019GantiPresiden Mantullll Brooo... } \\
\text { \#ReuniAkbar212 \#ReuniAkbar212diMonas }\end{array}$ \\
\hline Informasional & $\begin{array}{l}\text { @maulana_tigor: 08.50. Bukan hanya di Monas, Jama'ah \#ReuniAkbar212 di } \\
\text { Jl Thamrin juga berkumpul utk mendengarkan Tausiah2 dari Mobil Komando. } \\
\text { Luar biasa... \#Reuni212diMonas }\end{array}$ \\
\hline Ke-Islam-an & $\begin{array}{l}\text { @azizsyafiq12: Alhamdulillah Allahu Akbar! Terharu bisa menjadi bagian dari } \\
\text { jutaan umat islam di bawah naungan bendera tauhid. \#ReuniAkbar212 }\end{array}$ \\
\hline Keramaian Acara & $\begin{array}{l}\text { @ZAEffendy: } 217 \text { Ton sampah lenyap tak berbekas di lokasi tempat } \\
\text { berkumpulnya } 8 \text { juta lebih rakyat \#Indonesia peserta \#ReuniAkbar212 } \\
\text { \#ReuniAkbar212diMonas! Cuma peserta \#Reuni212 yang mampu \&amp; } \\
\text { bisa contohkan indahnya IMAN \&amp; TAOWA...LILLAHI TA'ALA }\end{array}$ \\
\hline Kritik Petahana & $\begin{array}{l}\text { @RabbaniProjects: Wajar, bila pendukung dan timses @jokowi kalap melihat } \\
\text { massa umat Islam yang hadir di \#ReuniAkbar212 Sudah tergambar peta } \\
\text { politik! Dan dunia internasional menyaksikan... \#iDeasRabbani }\end{array}$ \\
\hline Perdebatan & $\begin{array}{l}\text { @BangPino__: Mau tahu bedanya Mujahid NKRI dg Pasukan Nasi Bungkus??? } \\
\text { Simak perbedaan Aksi } 212 \text { dg Aksi 412. Dari sinilah kenapa mrk selalu iri dan } \\
\text { sakit hati terhadap Aksi Umat Islam. Selain mrk tdk punya massa, Logistikpun } \\
\text { jd bahan pertengkaran mrk. \#ReuniAkbar212 \#ReuniAkbar212diMonas }\end{array}$ \\
\hline Prabowo & $\begin{array}{l}\text { @MCAOps: Prabowo saat melakukan orasi di Reuni } 212 \text { di Monas. "Di sini juga } \\
\text { dihadiri tokoh agama lain. Ini bukti Islam di Indonesia adalah Islam yang damai } \\
\text { dan mempersatukan!" \#Reuni212 \#ReuniAkbar212 \#ReuniAkbar212diMonas }\end{array}$ \\
\hline
\end{tabular}

Paparan angka klasifikasi topik di atas menggambarkan bahwa mayoritas topik tweet pada komunitas virtual aksi Reuni 212 secara mayoritas bukan bertopik politik. Tiga topik "Ke-Islam-an", "Keramaian Acara" dan "Informasional" mendominasi jumlah tweet mencapai 712/1000 (71,2\%) bukan topik bertema politik, cenderung bersifat netral, sehingga tidak ada kepentingan untuk melakukan taktik digital masquerading. Hal ini melemahkan dugaan bahwasannya khalayak Twitter aksi Reuni 212 merupakan komunitas virtual yang berorientasi gerakan politik, sebab justru dibuktikan bahwa mayoritas pesan-pesan di dalam komunitas ini tidak bernada politik, namun netral dan cenderung mengangkat topik Islam dan laporan acara secara umum.

Meski demikian, 4 topik lainnya yakni topik "Prabowo", "Kritik Petahana",
"Perdebatan", dan "Ganti Presiden" adalah topik-topik tweet yang bertema politik, mencapai total 288/1000 tweet (28,8\%). Dari keseluruhan tweet tersebut, hasil observasi penulis menemukan bahwa tidak ada upaya-upaya untuk menghindari ujaran terbuka dalam mengkritik lawan politik yakni Jokowi dari kubu Presiden petahana. Hal ini menjadi ciri bahwa tidak kesadaran atau upaya untuk menghindari sensor apabila dilakukan pelanggaran kampanye di Twitter. Hal ini dibuktikan dengan tweettweet pada topik"Kritik Petahana" dan "Ganti Presiden" serta sebagian tweet pada topik "Perdebatan" yang secara terang-terangan mengkritik kubu Jokowi sebagai lawan calon Presiden Prabowo. Hasil pengamatan ini menyimpulkan bahwa tidak ada upaya taktik digital masquerading yang dilakukan oleh sebagian khalayak Twitter anggota 
komunitas virtual aksi Reuni 212 dalam rangka mengkritik Jokowi sebagai lawan Prabowo sebagai kandidat yang didukung.

\section{E. KESIMPULAN}

Paper ini berangkat dari fokus untuk mendalami bagaimana fenomena khalayak Aksi 212 di media sosial Twitter sebagai sebuah komunitas virtual (virtual community). Menggunakan landasan konseptual virtual community Howard Rheingold sebagai pendekatan analisis, serta metode analisis jaringan komunikasi untuk mengetahui pola struktur jaringan komunikasi komunitas yang terjadi, penulis menemukan bahwa 1000 pengguna Twitter yang termasuk dalam jaringan tagar \#ReuniAkbar212 pada 2 Desember 2018 merupakan sebuah fenomena komunitas virtual sebagaimana konsepsi Rheingold.

Kesimpulan di atas ditarik dari analisis bahwa komunitas virtual pengguna Twitter dalam jaringan tagar \#ReuniAkbar212 mencerminkan ciri-ciri komunitas virtual antara lain: adanya aktivitas komunikasi yang dimediasi komputer dan jaringan internet di antara para pengguna yang direpresentasikan oleh akun Twitter; aktivitas komunikasi yang terjadi tersebut dalam terminologi Twitter antara lain berupa tweeting, mentioning, replying, dan retweeting. Selain itu, analisis jaringan komunikasi menunjukkan bahwa terdapat beberapa aktor yang cenderung lebih banyak dirujuk (di-mention dan di-reply) daripada pengguna yang lain, tercermin dari pemusatan nodes pada sosiogram mention dan sosiogram reply.

Ciri-ciri lain dari komunitas virtual juga tercermin dari tweet yang penulis analisis, yakni: adanya etos berbagi informasi dalam komunitas yang ditunjukkan dengan tingginya jumlah tweet; dominasi anggota komunitas yang pasif serta adanya corak yang mengarah pada konsep gatekeeper pada anggota komunitas yang aktif menyusun tweet meskipun tidak ada kesepakatan; dan juga terdapat fenomena kepatuhan netiquette komunitas virtual berupa menghindari penggunaan hurufhuruf kapital agar tidak mengesankan kalimat teriakan.

Hasil analisis jaringan komunikasi menemukan bahwa jaringan komunikasi mention pada komunitas virtual Twitter aksi Reuni 212 memiliki konsentrasi pada akunakun berikut: @prabowo, @champbrb, @ marierteman\&@alex_wu (nodes berimpitan) @kapitraampera \& @ayahsidi77 (nodes berimpitan). Sementara pada jaringan reply cenderung bersifat jaringan yang menyebar dan tidak terdapat konsentrasi pada aktor tertentu. Meski demikian, adanya konsentrasi jaringan mention pada akun @prabowo dapat menjadi faktor untuk mempertimbangkan dugaan bahwa khalayak komunitas virtual tersebut sedang melakukan aktivitas komunikasi kampanye politik, sebab akun @prabowo adalah akun milik salah satu calon Presiden dengan nomor urut 2.

Sementara hasil analisis digital masquerading menemukan bahwa dominan topik komunikasi Twitter pada khalayak komunitas aksi Reuni 212 tidak bersifat politik (71,2\%). Sementara sisanya $28,8 \%$ memang bersifat komunikasi politik, namun tidak ditemukan ciri-ciri adanya kesadaran dan upaya taktis untuk menghindari sensor. Kritik-kritik dan argumentasi serangan terhadap kandidat Presiden dilakukan secara terbuka dan terang-terangan. Analisis ini menyimpulkan bahwa sebagian anggota komunitas virtual aksi Reuni 212 yang melakukan aktivitas komunikasi politik tidak melakukan taktik digital masquerading.

\section{DAFTAR PUSTAKA}

Abdulsalam, H. (2018, Desember 4). Reuni 212: Benarkah Klaim 8 Juta Peserta? Diambil kembali dari Tirto: https://tirto.id/reuni-212-benarkah-klaim-8-juta-peserta-daTm 
Bimber, B., Cunill, M. C., Copeland, L., \& Gibson, R. (2015). Digital Media and Political Participation: The Moderating Role of Political Interest Across Acts and Over Time. Social Science Computer Review, 21-42.

Casemajor, N., Couture, S., Delfin, M., Goerzen, M., \& Delfanti, A. (2015). Non-Participation in Dlgital Media: Toward a Framework of Mediated Political Action. Media, Culture \& Society, 850-866.

Dimitrova, D. V., Shehata, A., Strömbäck, J., \& Nord, L. W. (2014). The Effects of Digital Media on Political Knowledge and Participation in Election Campaigns: Evidence From Panel Data. Communication Research, 95-118.

Eriyanto. (2014). Analisis Jaringan Komunikasi: Strategi Baru dalam Penelitian Ilmu Komunikasi dan Ilmu Sosial Lainnya. Jakarta: Prenadamedia Group.

Howard, P. N., \& Hussain, M. M. (2013). Democracy's Fourth Wave? New York: Oxford University Press.

Littlejohn, S. W. (2002). Theories of Human Communication - Seventh Edition. New York: Wadsworth Group.

Long, P., \& Wall, T. (2013). Media Studies: Texts, Production, Context - Second Edition. New York: Routledge.

Rheingold, H. (2000). The Virtual Community: Homesteading on the Electronic Frontier. Massachusetts: MIT Press.

Schroeder, R. (2016). Rethinking Digital Media and Political Change. Convergence: The International Journal of Research into New Media Technologies, 1-16.

Tan, J. (2017). Digital Masquerading: Feminist Media Activism in China. Crime Media Culture, 171-186. 